\title{
Pelagic cephalopods of the central Mediterranean Sea determined by the analysis of the stomach content of large fish predators
}

\author{
Teresa Romeo $\cdot$ Pietro Battaglia $\cdot$ Cristina Pedà $\cdot$ \\ Patrizia Perzia • Pierpaolo Consoli • \\ Valentina Esposito · Franco Andaloro
}

Received: 14 March 2011 / Revised: 26 July 2011/Accepted: 28 July 2011/Published online: 10 August 2011

(C) Springer-Verlag and AWI 2011

\begin{abstract}
The pelagic cephalopod fauna of the central Mediterranean Sea was investigated through stomach content analyses of large fish predators. A total of 124 Xiphias gladius, 22 Thunnus thynnus, 100 Thunnus alalunga, and 25 Tetrapturus belone were analyzed. Overall, 3,096 cephalopods belonging to 23 species and 16 families were identified. The cephalopod fauna in the study area is dominated by Sepiolidae, Ommastrephidae, and Onychoteuthidae. The sepiolid Heteroteuthis dispar was the most abundant species $(n=1,402)$ while the ommastrephid Todarodes sagittatus showed the highest biomass. They can be considered key-species in the pelagic food web of the study area. The neutrally buoyant Histioteuthis bonnellii, H. reversa, and Chiroteuthis veranyi seem to characterize the deeper water layers. Given the difficulty in sampling pelagic cephalopods, the presence of cephalopod beaks in the stomach of predators represents a fundamental tool to assess the biodiversity and the ecological importance of these taxa in the marine ecosystem.
\end{abstract}

Communicated by H.-D. Franke.

T. Romeo $(\bowtie) \cdot$ P. Battaglia · C. Pedà · P. Consoli

V. Esposito

Laboratory of Milazzo, ISPRA,

Italian National Institute for Environmental

Protection and Research, via dei Mille 44,

98057 Milazzo, ME, Italy

e-mail: teresa.romeo@isprambiente.it

P. Perzia $\cdot$ F. Andaloro

ISPRA, Italian National Institute for Environmental

Protection and Research, c/o Residence Marbela,

via Salvatore Puglisi 9, 90143 Palermo, Italy
Keywords Pelagic cephalopods - Beaks - Large pelagic predators $\cdot$ Mediterranean Sea

\section{Introduction}

Knowledge of the pelagic cephalopod community has increased over the last decades thanks to improved techniques. However, there is still a significant lack of information on these animals' biology, distribution, and importance in the food web. This is mainly due to the difficulties associated with sampling, as conventional gears used in monitoring of the pelagic environment usually collect juvenile cephalopods, while adult specimens generally avoid being captured (Clarke 1996a).

Despite the difficulties in sampling, the ecological importance of cephalopods in the marine ecosystem has already been emphasized by several authors (Clarke 1996b; Bustamante et al. 1998; Piatkowski et al. 2001; Velasco et al. 2001). In particular, muscular squids are able to quickly convert their food into biomass and to grow rapidly. They, therefore, represent a significant source of energy for predators. Moreover, while most mid-water fishes do not grow bigger than $200 \mathrm{~mm}$ in length, many pelagic cephalopods grow up to larger sizes. They thus fill the gap between small fishes (i.e., myctophids, etc.) and large pelagic organisms, linking secondary production with higher trophic levels, as reported in energetic models of pelagic food webs (Clarke 1996b; Olson and Watters 2003).

Studies on the feeding habits of oceanic predators, including marine mammals and sea birds, revealed the actual role played by cephalopods in the pelagic food web (Amaratunga 1983; Clarke 1996b; Santos et al. 2001; Cherel et al. 2004). The identification of this taxon in the 
stomach content of top predators is often achieved via a taxonomic classification of their beaks, because these are quite resistant to digestive processes (Clarke 1962a, b). In this way, it is possible to describe the occurrence of pelagic cephalopods in an area and to obtain precious information on the ecology and behavior of cephalopods (Bello 1996; Tsuchiya et al. 1998; Cherel et al. 2004; Lansdell and Young 2007). Although several studies underlined the significant presence of cephalopod prey in the diet of large Mediterranean pelagic fishes (Bello 1991; Bello 1999; Salman 2004; Sinopoli et al. 2004; Peristeraki et al. 2005; Sarà and Sarà 2007; Castriota et al. 2008; Consoli et al. 2008; Karakulak et al. 2009; Salman and Karakulak 2009; Romeo et al. 2009), data on the specific composition and distribution of pelagic cephalopod communities in the Mediterranean are still poor.

In the present paper, stomach content analyses of large predators were performed to assess the occurrence and distribution of cephalopods in the Central Mediterranean Sea (southern Tyrrhenian Sea and Strait of Messina). To select for the most effective "cephalopod collectors," data on the species' different ecology and feeding strategy were considered. Large pelagic species usually hunt across a specific water layer at varying-although sometimes overlapping - depth levels. Considering differences between species in diving behavior, feeding strategies, and occurrence in the study area, the following top predators were selected: (1) swordfish, Xiphias gladius Linnaeus 1758; (2) blue-fin tuna, Thunnus thynnus (Linnaeus 1758); (3) albacore, Thunnus alalunga (Bonnaterre 1788); and (4) Mediterranean spearfish, Tetrapturus belone Rafinesque 1810.

\section{Materials and methods}

Study area

This study was carried out between 2002 and 2008 in the central Mediterranean Sea (southern Tyrrhenian Sea and Strait of Messina) (Fig. 1). A very small continental shelf and the presence of important fish resources (Palko et al. 1981; Di Natale et al. 2005; Andaloro 2006; Battaglia et al. 2010) consolidated a fishing tradition targeting large pelagic species, which use these areas for reproduction and nursery purposes (Palko et al. 1981; De Metrio et al. 2005). In fact, since ancient times this area has represented an important fishing ground for the local populations, where several types of fisheries have been employed: harpoon, hand lines, tuna traps, and in the last decades also driftnets and longlines (Lentini and Romeo 2000; Di Natale and Mangano 2008; Battaglia et al. 2010). The Strait of Messina, in particular, is well known as an important migration and feeding area of large pelagic species, where upwelling phenomena result in high nutrient concentrations and prey biomass (Guglielmo et al. 1995).

\section{Data collection}

Stomachs were collected during commercial fishing activities within different research projects between 2002 and 2008 aboard boats using drifting long-lines (three different types of equipment targeting $T$. alalunga, T. thynnus, and $X$. gladius, respectively) and harpoon ("feluca" boats targeting $X$. gladius and $T$. belone). Each predator specimen
Fig. 1 Study area in the central Mediterranean Sea

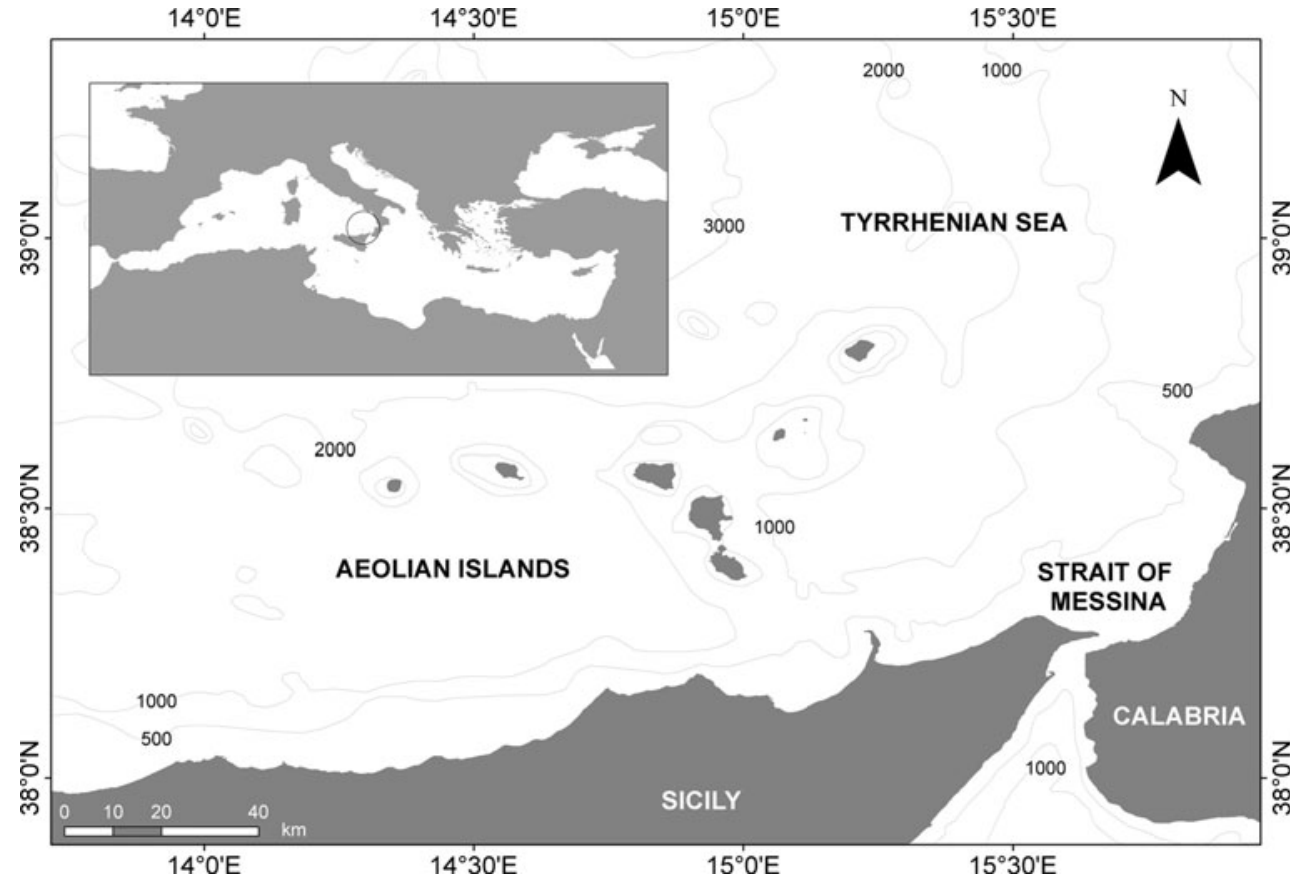


was measured and weighed (TW = total weight in $\mathrm{kg}$ ) on board. Lower jaw fork length (LJFL, expressed in $\mathrm{cm}$ ) was recorded for swordfish and Mediterranean spearfish, while fork length (FL, expressed in $\mathrm{cm}$ ) was recorded for blue-fin tuna and albacore. Stomachs were immediately removed from the fish specimens and preserved in order to stop the digestion process, using three methods: (1) preservation in formalin/sea water solution for $24 \mathrm{~h}$ and subsequent transfer into $80 \%$ ethanol; (2) conservation in $70 \%$ ethanol; (3) freezing at $-20^{\circ} \mathrm{C}$.

\section{Laboratory analyses}

Stomachs were dissected in the laboratory, and their content was examined under a stereomicroscope. Entire specimens or partially digested cephalopods were identified to the lowest possible taxa, following taxonomic features reported by Roper et al. (1984), Jereb and Roper (2005), and Guerra (1992). When classification turned out to be difficult, beaks were taken as the best means to identify the species. A large portion of cephalopods was determined by lower beak identification, since the beaks were often the only structures found in stomachs. Their classification was performed by identification keys (Wolff 1982, 1984; Clarke 1986; Lu and Ickeringill 2002) and by comparison with beaks of the ISPRA reference collection (Pedà et al. 2009).

The identified preys were counted and weighed; entire specimens were preserved in $70 \%$ ethanol, while beaks were immersed in a mixture of ethanol, glycerin, and water.

\section{Data analyses}

In order to trace back cephalopods' size and fresh weight, the lower rostrum length (LRL) for Teuthida and the lower hood length (LHL) for Sepiolidea and Octopoda were measured to the nearest $0.1 \mathrm{~mm}$. When the wet mass of prey was not available (i.e., when it had already been more or less digested), this value was calculated using equations available from Wolff (1982, 1984), Clarke (1962a, 1986), Lu and Ickeringill (2002), Zumholz and Piatkowski (2005) or calculated from specimens preserved in the ISPRA reference collection (Table 1).

To assess the cephalopod abundance in the study area through diet information, the percent abundance $(\% \mathrm{~N}=$ number of prey $\mathrm{i} /$ total number of prey $\times 100)$, estimated weight percentage $(\% e W=$ weight of prey $\mathrm{i} /$ total weight of prey $\times 100)$, and frequency of occurrence $(\% F=$ number of stomachs containing prey i/total number of stomachs containing prey $\times 100)$ were calculated for each cephalopod prey taxon (Pinkas et al. 1971; Hyslop 1980), and for each predator species.
Finally, in order to evaluate the importance of the prey mass for the diet of each predator, all cephalopods were grouped into four weight classes (small $=0-50 \mathrm{~g}$; medium/ small $=51-100 \mathrm{~g} ;$ medium $=101-300 \mathrm{~g}$; large $\geq 300 \mathrm{~g}$ ) and also into the following categories: muscular squids, buoyant squids, sepiolids, pelagic octopuses, and demersal octopuses. The percentage of each category per each mass group was calculated for each predator diet.

\section{Results}

Overall, 3,096 cephalopods belonging to 16 families and 23 species (Table 2) were identified through the analysis of the stomach content of 124 swordfishes (LJFL range $65-225 \mathrm{~cm}$ ), 22 blue-fin tunas (FL range 45-270 cm), 100 albacores (FL range 48-91 cm), and 25 Mediterranean spearfishes (LJFL range 120-189 cm). In terms species number, the most represented families in the study area were the Ommastrephidae (4) and the Octopodidae (3). With 1,402 specimens, the sepiolid Heteroteuthis dispar (Rüppell, 1845) was the most abundant species in the area, although its biomass was low due to the small maximum size of this species. Ommastrephidae, especially Todarodes sagittatus (Lamarck 1798) and Illex coindetii (Vérany 1839), and Onychoteuthidae as Onychoteuthis banksii (Leach 1817) and Ancistroteuthis lichtensteinii (Férussac and d'Orbigny 1835) represented a consistent part of the local cephalopod fauna. The highest values of biomass were estimated for $T$. sagittatus (46,098.2 g). Similar values were reached by Thysanoteuthis rhombus Troschel 1857, but these resulted from just a few $(n=6)$ large individuals (Table 2).

A total of 1,032 cephalopods were recorded from swordfish (8.3 prey/predator), 131 from bluefin tuna (5.9 prey/predator), 1,876 from albacore (18.8 prey/predator), and 57 from Mediterranean spearfish (2.3 prey/predator) (Table 3). The cephalopods $T$. sagittatus, O. banksii, I. coindetii, Histioteuthis reversa (Verrill 1880), Ancistrocheirus lesueurii (Férussac and d'Orbigny 1842), and Argonauta argo (Linnaeus 1758) were preyed by all pelagic fish species studied. In contrast, some taxa were found only in the stomachs of a single predator species: Abralia veranyi (Rüppell 1844), Galiteuthis armata (Joubin 1898), and Octopoteuthis cfr. sicula (Rüppell 1844) in swordfish; Todaropsis eblanae in bluefin tuna; Alloteuthis subulata (Lamarck 1798) and Scaeurgus unicirrhus (Delle Chiaje 1840) in albacore. Table 3 also shows the average values of beak size (LRL or LHL in $\mathrm{mm}$ ) and body mass ( $e W$ in $\mathrm{g}$ ) for each cephalopod.

The abundance percentage $(\% N)$, estimated weight percentage $(\% \mathrm{eW})$, and frequency of occurrence $(\% F)$ of cephalopod species and families are listed in Table 4. 


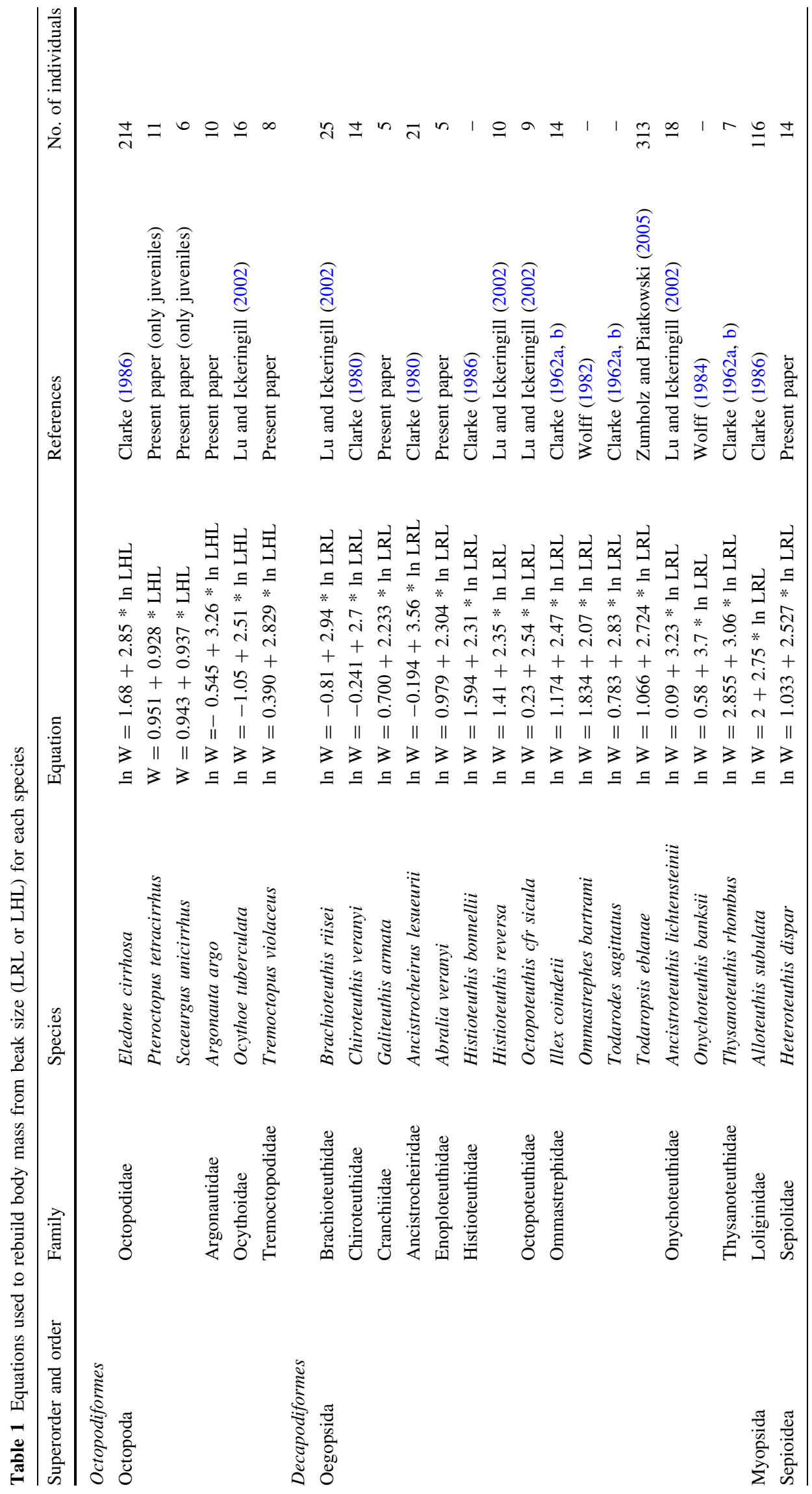


Table 2 Total number $(N)$ and estimated weight $(\mathrm{eW})$ of each cephalopod species identified from the stomach contents of large pelagic predators caught in the central Mediterranean, together mean values of beak size (LRL or LHL in $\mathrm{mm}$ ) and estimated cephalopod weight (eW)

\begin{tabular}{|c|c|c|c|c|c|c|c|c|}
\hline \multirow{2}{*}{$\begin{array}{l}\text { Superorder } \\
\text { and order }\end{array}$} & \multirow[t]{2}{*}{ Family } & \multirow[t]{2}{*}{ Cephalopod species } & \multirow[t]{2}{*}{$N$} & \multirow[t]{2}{*}{$e W(\mathrm{~g})$} & \multicolumn{2}{|c|}{ LRL/LHL (mm) } & \multicolumn{2}{|l|}{$e W(\mathrm{~g})$} \\
\hline & & & & & Mean & SD & Mean & SD \\
\hline \multicolumn{9}{|c|}{ Octopodiformes } \\
\hline \multirow[t]{6}{*}{ Octopoda } & Octopodidae & Eledone cirrhosa (Lamarck, 1798) & 2 & 4.8 & 0.8 & - & 2.4 & - \\
\hline & & Pteroctopus tetracirrhus (Delle Chiaje, 1830) & 67 & 104.2 & 0.7 & 0.2 & 1.6 & 0.2 \\
\hline & & Scaeurgus unicirrhus (Delle Chiaje, 1840) & 30 & 45.1 & 0.6 & 0.1 & 1.5 & 0.1 \\
\hline & Argonautidae & Argonauta argo Linnaeus, 1758 & 47 & 456.2 & 2.1 & 1.5 & 8.6 & 12.2 \\
\hline & Ocythoidae & Ocythoe tuberculata Rafinesque, 1814 & 18 & 106.7 & 2.1 & 1.8 & 5.5 & 7.5 \\
\hline & Tremoctopodidae & Tremoctopus violaceus Delle Chiaje, 1830 & 81 & $11,192.6$ & 2.5 & 1.5 & 138.2 & 509.9 \\
\hline \multicolumn{9}{|c|}{ Decapodiformes } \\
\hline \multirow[t]{15}{*}{ Oegopsida } & Brachioteuthidae & Brachioteuthis riisei (Steenstrup, 1882) & 6 & 38.8 & 2.4 & 0.4 & 6.5 & 2.7 \\
\hline & Chiroteuthidae & Chiroteuthis veranyi (Férussac, 1835) & 20 & 260.1 & 2.4 & 1.1 & 13.0 & 18.6 \\
\hline & Cranchiidae & Galiteuthis armata Joubin, 1898 & 16 & 178.1 & 2.6 & 0.9 & 11.1 & 17.4 \\
\hline & Ancistrocheiridae & $\begin{array}{l}\text { Ancistrocheirus lesueurii (Férussac } \\
\text { and d'Orbigny, 1842) }\end{array}$ & 16 & $1,493.7$ & 2.0 & 2.1 & 92.9 & 189.5 \\
\hline & Enoploteuthidae & Abralia veranyi (Rüppell, 1844) & 4 & 8.7 & 1.5 & 0.4 & 2.2 & 1.2 \\
\hline & Histioteuthidae & Histioteuthis bonnellii (Férussac, 1835) & 21 & 797.4 & 2.1 & 1.0 & 38.0 & 52.3 \\
\hline & & Histioteuthis reversa (Verrill, 1880) & 27 & 1053.2 & 2.9 & 0.7 & 55.7 & 29.8 \\
\hline & Octopoteuthidae & Octopoteuthis cfr sicula Rüppell, 1844 & 1 & 935.3 & - & - & - & - \\
\hline & Ommastrephidae & Illex coindetii (Vérany, 1839) & 152 & $11,259.8$ & 3.1 & 1.6 & 74.1 & 65.2 \\
\hline & & Ommastrephes bartrami (Lesueur, 1821) & 39 & $6,611.5$ & 4.2 & 2.5 & 169.5 & 256.9 \\
\hline & & Todarodes sagittatus (Lamarck, 1798) & 565 & $46,098.2$ & 2.7 & 1.8 & 81.6 & 122.5 \\
\hline & & Todaropsis eblanae (Ball, 1841) & 2 & 273.8 & 3.7 & - & 136.9 & - \\
\hline & Onychoteuthidae & $\begin{array}{l}\text { Ancistroteuthis lichtensteinii (Férussac } \\
\text { and d'Orbigny, 1835) }\end{array}$ & 302 & $11,335.0$ & 2.4 & 1.2 & 37.5 & 53.5 \\
\hline & & Onychoteuthis banksii (Leach, 1817) & 270 & $2,587.1$ & 1.2 & 0.6 & 9.6 & 22.5 \\
\hline & Thysanoteuthidae & Thysanoteuthis rhombus Troschel, 1857 & 6 & $45,192.0$ & 5.6 & 3.7 & $7,532.0$ & $11,263.5$ \\
\hline Myopsida & Loliginidae & Alloteuthis subulata (Lamarck, 1798) & 2 & 7.7 & 0.8 & - & 3.9 & - \\
\hline Sepioidea & Sepiolidae & Heteroteuthis dispar (Rüppell, 1845) & 1,402 & $1,317.9$ & 0.9 & 0.2 & 0.8 & 1.3 \\
\hline
\end{tabular}

T. sagittatus $(\% N=30.52 ; \% e W=36.53 ; \% F=62.9)$ and A. lichtensteinii $(\% N=19.57 ; \% e W=8.69 ; \% F=48.4)$ were the most important cephalopods detected in swordfish stomachs, whereas blue-fin tuna preyed mainly on Tremoctopus violaceus Delle Chiaje $1830(\% N=36.64 ; \%$ eW $=$ $37.86 ; \% F=36.4)$ and $T$. sagittatus $(\% N=19.85 ; \% e W=$ $6.80 ; \% F=59.1)$. $H$. dispar $(\% N=65.03 ; \% e W=24.04$; $\% F=66.0$ ) was found to be the preferential prey for albacore, followed by $T$. sagittatus $(\% N=11.78 ; \% \mathrm{eW}=$ $24.10 ; \% F=46.0)$ and $O$. banksii $(\% N=9.65 ; \% e W=$ 24.43; $\% F=57.0)$. Mediterranean spearfish preyed mostly on the epipelagic cephalopod $T$. violaceus $(\% N=24.56$; $\% e W=22.29 ; \% F=1.8)$ and the ommastrephid $I$. coindetii $(\% N=22.81 ; \% e W=23.08 ; \% F=1.5)$.

The analysis of cephalopod body mass in predator diet shows a clear dominance of muscular squids of all weight classes (0-50 g; 51-100 g; 101-300 g; >300 g) in swordfish and blue-fin tuna food items (Fig. 2). These cephalopods were less represented in samples collected from Mediterranean spearfish, as this fish also preyed on pelagic octopuses and buoyant squids. The pelagic octopuses constituted a consistent part of blue-fin tuna prey for all weight classes. The albacore showed selective feeding on small prey (99.6\% of total prey), in particular sepiolids (65.0\%). Moreover, this predator is able to collect also juvenile specimens of demersal octopuses (5.1\%), which have not yet settled on the bottom.

\section{Discussion}

The present study investigated the presence and distributional patterns of pelagic cephalopods by assessing the importance of these species in the diet of large predatory fish, which are considered efficient "cephalopod collectors." In fact, the analysis of the stomach content of apex 


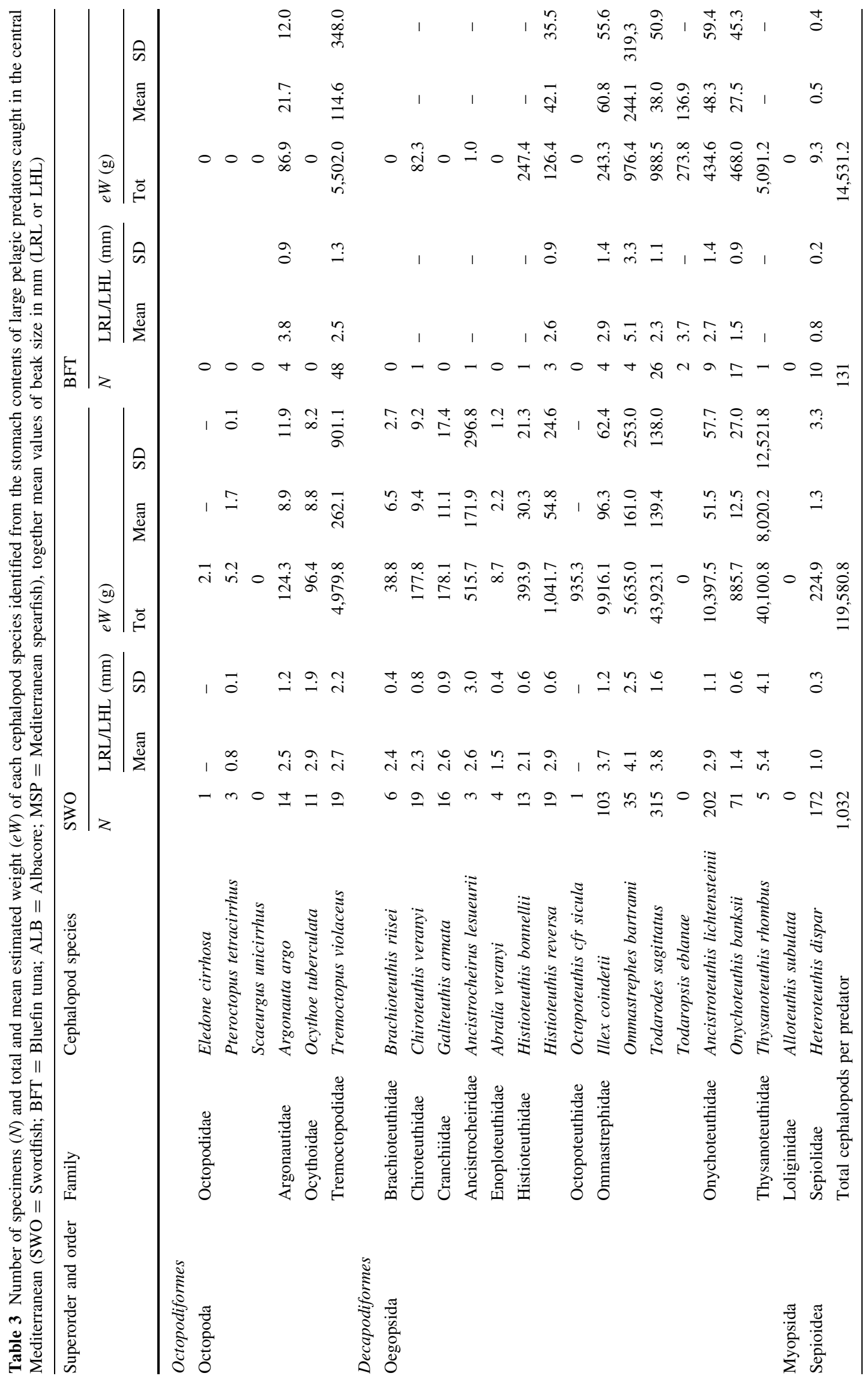




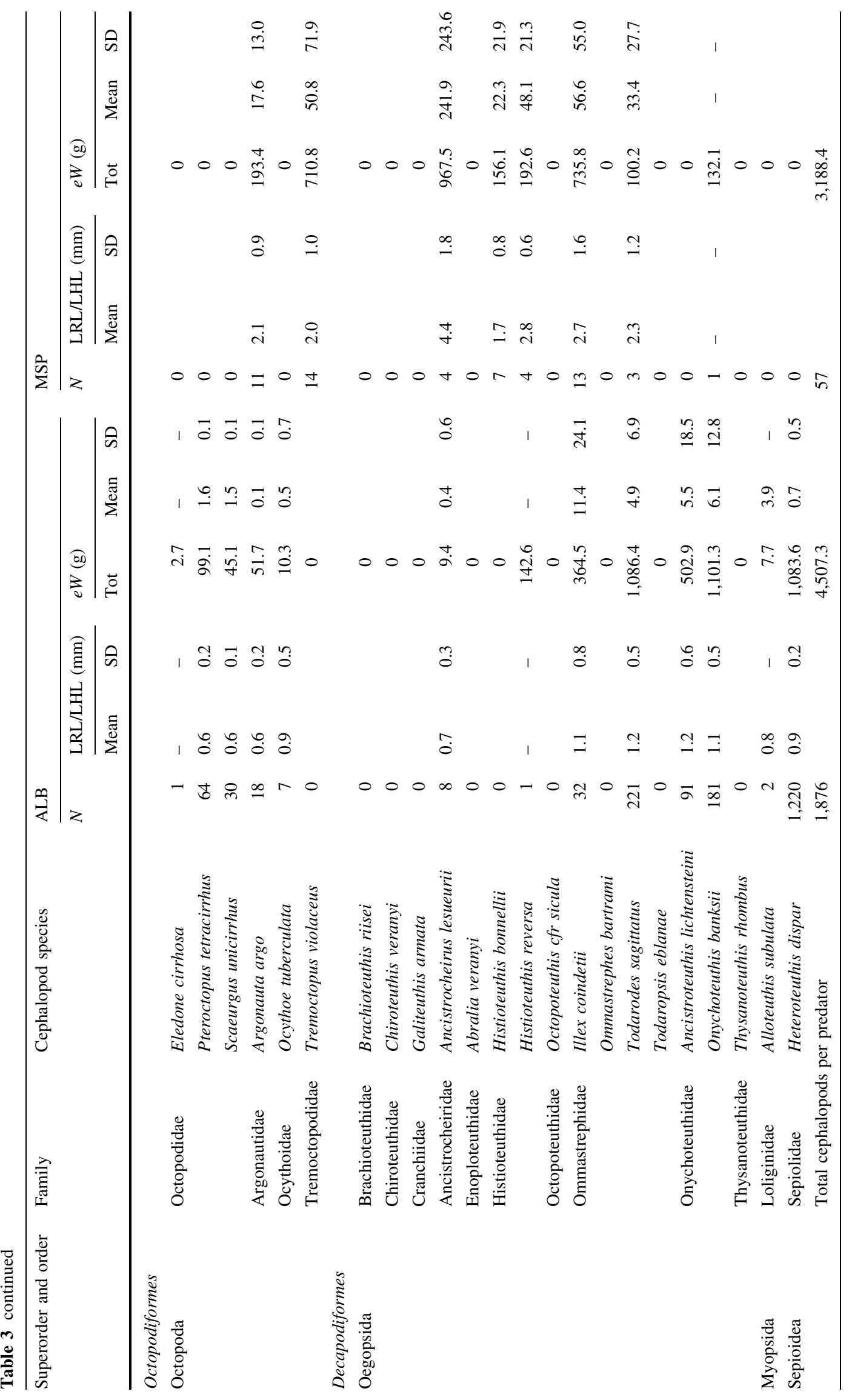


Table 4 Abundance percentage $(\% N)$, estimated weight percentage $(\% \mathrm{eW})$ and frequency of occurrence $(\% F)$ of cephalopod prey (species and family) identified from the stomach contents of large pelagic predators caught in the central Mediterranean $(\mathrm{SWO}=$ Swordfish $; \quad \mathrm{BFT}=$ Blue-fin $\quad$ tuna $; \quad \mathrm{ALB}=$ Albacore $\mathrm{MSP}=$ Mediterranean spearfish)

\begin{tabular}{|c|c|c|c|c|c|c|c|c|c|c|c|c|c|}
\hline \multirow[t]{2}{*}{ Superorder and order } & \multirow[t]{2}{*}{ Prey types } & \multicolumn{3}{|c|}{ SWO } & \multicolumn{3}{|l|}{ BFT } & \multicolumn{3}{|l|}{ ALB } & \multicolumn{3}{|c|}{ MSP } \\
\hline & & $\% N$ & $\% e W$ & $\% F$ & $\% N$ & $\% e W$ & $\% F$ & $\% N$ & $\% e W$ & $\% F$ & $\% N$ & $\% e W$ & $\% F$ \\
\hline \multicolumn{14}{|l|}{ Octopodiformes } \\
\hline \multirow[t]{7}{*}{ Octopoda } & Octopodidae & 0.4 & $<0.1$ & 2.4 & - & - & - & 5.1 & 3.3 & 24.0 & - & - & - \\
\hline & E. cirrhosa & 0.1 & $<0.1$ & 0.8 & - & - & - & 0.1 & 0.1 & 1.0 & - & - & - \\
\hline & P. tetracirrhus & 0.3 & $<0.1$ & 1.6 & - & - & - & 3.4 & 2.2 & 24.0 & - & - & - \\
\hline & S. unicirrhus & - & - & - & - & - & - & 1.6 & 1.0 & 5.0 & - & - & - \\
\hline & Argonautidae (A. argo) & 1.4 & 0.1 & 7.3 & 3.1 & 0.6 & 18.2 & 1.0 & 1.1 & 10.0 & 19.3 & 6.1 & 2.0 \\
\hline & Ocythoidae (O. tuberculata) & 1.1 & 0.1 & 5.6 & - & - & - & 0.4 & 0.2 & 4.0 & - & - & - \\
\hline & Tremoctopodidae (T. violaceus) & 1.8 & 4.2 & 4.8 & 36.6 & 37.9 & 36.4 & - & - & - & 24.6 & 22.3 & 1.8 \\
\hline \multicolumn{14}{|l|}{ Decapodiformes } \\
\hline \multirow[t]{19}{*}{ Oegopsida } & Brachioteuthidae (B. riisei) & 0.6 & $<0.1$ & 3.2 & - & - & - & - & - & - & - & - & - \\
\hline & Chiroteuthidae (C. veranyi) & 1.8 & 0.1 & 5.6 & 0.8 & 0.6 & 4.5 & - & - & - & - & - & - \\
\hline & Cranchiidae (G. armata) & 1.6 & 0.1 & 6.5 & - & - & - & - & - & - & - & - & - \\
\hline & Ancistrocheiridae (A. lesueurii) & 0.3 & 0.4 & 2.4 & 0.8 & $<0.1$ & 4.5 & 0.4 & 0.2 & 7.0 & 7.0 & 30.3 & 0.8 \\
\hline & Enoploteuthidae (A. veranyi) & 0.4 & $<0.1$ & 2.4 & - & - & - & - & - & - & - & - & - \\
\hline & Histioteuthidae & 3.1 & 1.2 & 15.3 & 3.1 & 2.6 & 13.6 & 0.1 & 3.2 & 1.0 & 19.3 & 10.9 & 1.5 \\
\hline & H. bonnellii & 1.3 & 0.3 & 7.3 & 0.8 & 1.7 & 4.5 & - & - & - & 12.3 & 4.9 & 0.8 \\
\hline & H. reversa & 1.8 & 0.9 & 8.9 & 2.3 & 0.9 & 9.1 & 0.1 & 3.2 & 1.0 & 7.0 & 6.0 & 1.0 \\
\hline & Octopoteuthidae (O. cfr sicula) & 0.1 & 0.8 & 0.8 & - & - & - & - & - & - & - & - & - \\
\hline & Ocythoidae (O. tuberculata) & 1.1 & 0.1 & 5.6 & - & - & - & 0.4 & 0.2 & 4.0 & - & - & - \\
\hline & Ommastrephidae & 43.9 & 49.7 & 79.8 & 27.5 & 17.1 & 63.6 & 13.5 & 32.2 & 48.0 & 28.1 & 26.2 & 2.0 \\
\hline & I. coindetii & 10.0 & 8.3 & 37.9 & 3.1 & 1.7 & 13.6 & 1.7 & 8.1 & 18.0 & 22.8 & 23.1 & 1.5 \\
\hline & O. bartrami & 3.4 & 4.7 & 18.5 & 3.1 & 6.7 & 13.6 & - & - & - & - & - & - \\
\hline & T. sagittatus & 30.5 & 36.7 & 62.9 & 19.8 & 6.8 & 59.1 & 11.8 & 24.1 & 46.0 & 5.3 & 3.1 & 0.5 \\
\hline & T. eblanae & - & - & - & 1.5 & 1.9 & 9.1 & - & - & - & - & - & - \\
\hline & Onychoteuthidae & 26.5 & 9.4 & 58.9 & 19.8 & 6.2 & 54.6 & 14.5 & 35.6 & 58.0 & 1.8 & 4.1 & 0.3 \\
\hline & A. lichtensteini & 19.6 & 8.7 & 48.4 & 6.9 & 3.0 & 31.8 & 4.9 & 11.2 & 33.0 & - & - & - \\
\hline & O. banksii & 6.9 & 0.7 & 21.8 & 13.0 & 3.2 & 31.8 & 9.6 & 24.4 & 57.0 & 1.8 & 4.1 & 0.3 \\
\hline & Thysanoteuthidae (T. rhombus) & 0.5 & 33.5 & 2.4 & 0.8 & 35.0 & 4.5 & - & - & - & - & - & - \\
\hline Myopsida & Loliginidae (A. subulata) & - & - & - & - & - & - & 0.1 & 0.2 & 1.0 & - & - & - \\
\hline Sepioidea & Sepiolidae (H. dispar) & 16.7 & 0.2 & 33.9 & 7.6 & 0.1 & 13.6 & 65.0 & 24.0 & 66.0 & - & - & - \\
\hline
\end{tabular}

predators is a significant source of data to describe this component of the marine fauna (Tsuchiya et al. 1998; Lansdell and Young 2007). Limitations of this method could be related to the retention of larger beaks in the stomachs of predators for several days (Santos et al. 2001) and to the migratory behavior of large pelagic predators. To minimize potential biases, four "cephalopod-samplers" were considered which differed in size, feeding habits, and preferential habitats were. In fact, the presence of cephalopods in the diet of large pelagics is strictly related to the water layer where the predator usually feeds and to its capability to carry out vertical movements.

Much information on horizontal and vertical migration was recently acquired by tagging experiments with swordfish (Carey and Robinson 1981; Takahashi et al. 2003;
Canese et al. 2004, 2008), blue-fin tuna (Lutcavage et al. 2000; Block et al. 2001, 2005), and albacore (Arrizabalaga et al. 2002; Cosgrove et al. 2006). Swordfish perform vertical excursions, reaching depths up to $800 \mathrm{~m}$ during daylight and remaining near the surface at night (Carey and Robinson 1981; Carey 1990; Takahashi et al. 2003). Their diel vertical excursions are usually discontinouos and frequently interrupted by vertical rises (Canese et al. 2008).

Blue-fin tuna follows a similar behavioral path, diving to depth $>600 \mathrm{~m}$ (Block et al. 2001), whereas the albacore depth range varies from the surface layers to $450 \mathrm{~m}$ (Bard 2001). While these three species are usually able to explore a large part of the water column, the Mediterranean spearfish does not seem to dive deeper than the thermocline (Nakamura 1985), as reported in studies on its feeding 
Fig. 2 Prey species composition (\%) within the four weight ranges $(0-50 ; 51-100$; $101-300 ;>300 \mathrm{~g}$ ) in the stomach content of predator species ( $S W O$ swordfish, $B F T$ bluefin tuna, $A L B$ albacore, MSP Mediterranean spearfish)

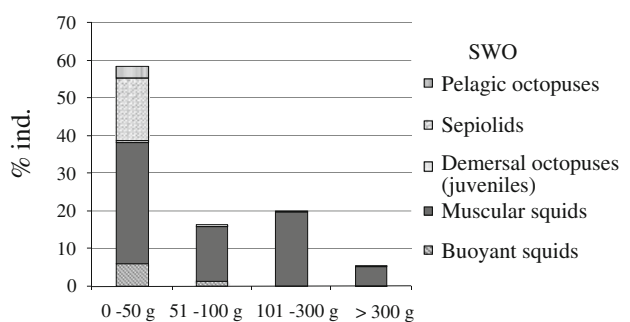

prey weight classes

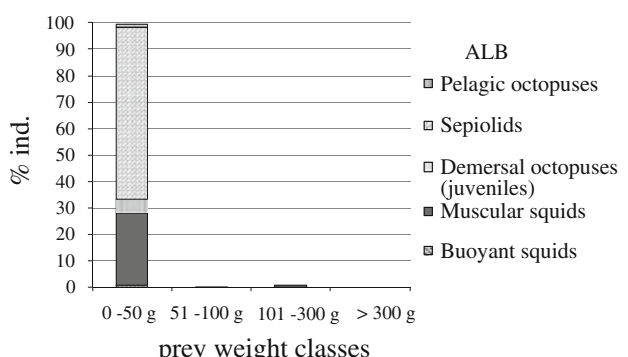

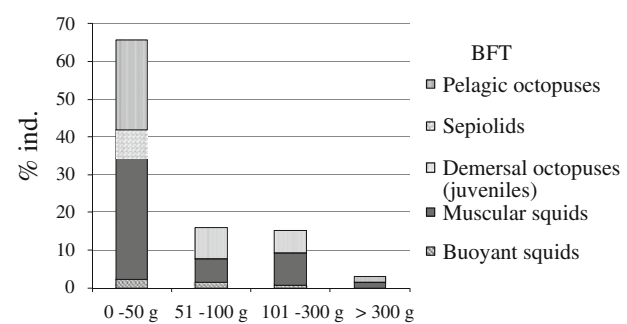

prey weight classes

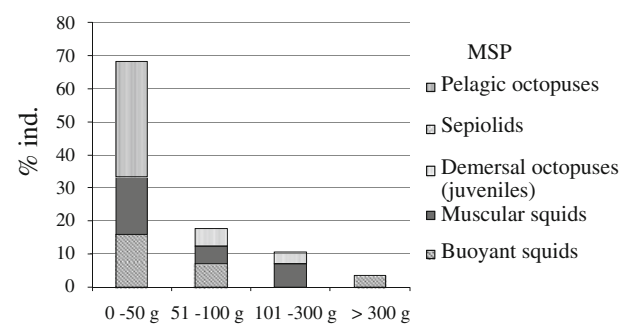

prey weight classes behavior in the Mediterranean Sea (Castriota et al. 2008; Romeo et al. 2009).

The analysis of cephalopod prey from a large number of stomachs of $X$. gladius, T. thynnus, T. alalunga, and $T$. belone provides a clearer picture of the pelagic cephalopod fauna in a macro-area of the central Mediterranean Sea (southern Tyrrhenian Sea and Strait of Messina). Cephalopods in the study area are mainly dominated by Sepiolidae, Ommastrephidae, and Onychoteuthidae. The pelagic Sepiolidae are only represented by $H$. dispar. The high number of specimens $(n=1,402)$ found in the present study as well as the huge biomass of this species recorded in other areas (Bello 1999; Salman and Karakulak 2009) suggest this squid being a key-species in the Mediterranean pelagic food web. In particular, $H$. dispar is an important food item for $T$. alalunga since this fish usually hunts small prey aggregated in schools (Bello 1999; Consoli et al. 2008). In fact, $H$. dispar is a small-sized sepiolid that usually lives in groups in lower epipelagic and in mesopelagic zones, most commonly in depths between 200 and 300 m (Jereb and Roper 2005).

The greatest overall prey biomass was represented by Ommastrephidae (especially T. sagittatus, O. bartramii, and $I$. coindetii) and Onychoteuthidae (O. banksii and $A$. lichtensteinii), highlighting the importance of these widely distributed families in the pelagic ecosystem of the area. Moreover, it is well known that these muscular fastswimming squids are high-speed growing active predators, which efficiently convert their prey into own biomass (Clarke 1996b), thus representing a primary source of energy for large marine fishes. The importance of the Ommastrephidae in the study area, especially in the area around the Aeolian Islands, is also confirmed by the presence of a specific professional fishing activity by squid hand-jig lines targeting T. sagittatus (Battaglia et al. 2010).

The neutrally buoyant and slowly swimming ammoniacal squids belonging to the Histioteuthidae, Histioteuthis bonnellii (Férussac 1835) and H. reversa, and to the Chiroteuthidae, Chiroteuthis veranyi (Férussac 1835) seem to characterize the deeper water layers in the study area. This is confirmed by their morphological features (e.g., the presence of light organs) as well as by their occurrence mainly in swordfish stomachs (i.e., in that predator which carries out feeding excursions to deep water layers). The abundance of Histioteuthidae in deeper waters was also recorded in other Mediterrranean areas, such as Spanish waters (Quetglas et al. 2010), where H. bonnellii and $H$. reversa show a spatial segregation with peaks of occurrence at 500-600 $\mathrm{m}$ and $600-700 \mathrm{~m}$ depth, respectively. Moreover, Quetglas et al. (2010) reported an increase in mean size of $H$. revers $a$ with depth, indicating an ontogenetic migration to deeper waters. Therefore, the species' abundance might be even higher than reported in the present paper, because of the limited bathymetric range in which predators are usually hunting.

The occurrence of some specimens of neutrally buoyant squids in the diet of the surface-feeding predator $T$. belone may be due to the upwelling currents in the Strait of Messina that concentrates deep fauna in the area, and to the species' diel vertical migrations to shallow depths at night (Quetglas et al. 2010).

Pelagic octopuses (T. violaceus, A. argo, and Ocythoe tuberculata Rafinesque 1814), belonging to the Argonauthoidea, inhabit epipelagic waters of the study area and, according to our results, seem to be more common than previously thought. These cephalopods occur in near-surface waters and rarely descend below the thermocline 
(Voss 1953; Thomas 1977; Bello 1993). For this reason, $T$. violaceus and $A$. argo represented a consistent part of the cephalopods collected by the surface-feeding T. belone. A clear preference for $T$. violaceus was showed for the predator $T$. thynnus, as it was also reported also by Karakulak et al. (2009) for the eastern Mediterranean Sea.

The occurrence of small specimens of the demersal species Eledone cirrhosa (Lamarck 1798), Pteroctopus tetracirrhus (Delle Chiaje 1830), and S. unicirrhus is likely to be due to the local presence of schools of juveniles (Giordano et al. 2010). Pelagic predators can take advantage of demersal octopuses as long as their young stages have not yet settled on the bottom.

On the other hand, records of both adult and juvenile individuals of a prey species in the stomachs of several cephalopods (A. lichtensteinii, H. dispar, I. coindetii, O. banksii, $T$. rhombus, and $T$. sagittatus) indicate that these species are likely to complete their entire life cycle in this area.

The present study also provided the opportunity to improve our knowledge on the distribution of some scarcely known and rare cephalopod species. A large beak $(\mathrm{LRL}=14.1 \mathrm{~mm})$ probably belonging to a specimen of the octopoteuthid Octopoteuthis sicula (Rüppell 1844) was found in a swordfish stomach. Large individuals of this species have never been recorded before, and among the few specimens caught until now, most records remained uncertain (Villari and Ammendolia 2009). This new data suggest that $O$. sicula can reach a larger size and that the growth of this species should be revaluated. Other rare cephalopods recorded in the study area were $A$. veranyi and G. armata.

The highest number of different prey species (20) was recorded in swordfish stomachs. This indicates that $X$. gladius can be considered the most efficient "cephalopod collector" that probably relates to the species' hunting behavior during large vertical migrations (Canese et al. 2008). Both epipelagic (T. violaceus, A. argo, etc.) and deep-water cephalopods ( $C$. veranyi, $H$. bonnellii, $H$. reversa, $O$. cfr sicula, and $A$. veranyi) were recorded in its diet. The intake of cephalopod prey species that follow a dial vertical migration pattern seems to be important for all predators except for $T$. belone. This species usually hunts above the thermocline and mainly during daylight, therefore not exploiting the vertical migrations of several cephalopods at night time (Castriota et al. 2008; Romeo et al. 2009).

In the light of the results achieved so far, analyses of the diet of pelagic predators are still the best tool to investigate the cephalopod community in pelagic areas (Cherel et al. 2004). In this context, the collection of cephalopod beaks in the stomachs of predators is a fundamental part in assessing the importance of cephalopods in the marine food web and in understanding the cephalopod diversiy in pelagic waters. Therefore, as far as the Mediterranean Sea is concerned, diagnostic tools for cephalopod beak identification (Clarke 1977) should be improved.

Acknowledgments The authors are grateful to Dr. G. Bello for his help in the classification of some beaks and to A. Villari and G. Ammendolia for their contribution in identifying rare species, thanks to their personal cephalopod collections, made up from stranding specimens in the Strait of Messina. The authors would also like to acknowledge the collaboration of the fishermen during sampling operations.

\section{References}

Amaratunga $\mathrm{T}$ (1983) The role of cephalopods in the marine ecosystems. FAO Fish Tech Pap 231:379-415

Andaloro F (2006) Gruppo di studio ed elementi di base per la gestione dei grandi pelagici. Sottoprogetto-Ruolo trofico del grande pelagico Thunnus alalunga, Bonnaterre 1788. Final report, Ministero per le Politiche Agricole e Forestali, pp 71

Arrizabalaga H, Rodas Lopez V, Ortis de Zarate V, Costa E, González Garcés A (2002) Study on the migrations and stock structure of albacore (Thunnus alalunga) from the Atlantic Ocean and the Mediterranean Sea based on conventional tag release-recapture experiences. ICCAT Coll Vol Sci Pap 54(5):1479-1494

Bard F (2001) Extension of geographical and vertical habitat of Albacore (Thunnus alalunga) in the North Atlantic possible consequences on true rate of exploitation of this stock. ICCAT Coll Vol Sci Pap 52(4):1447-1456

Battaglia P, Romeo T, Consoli P, Scotti G, Andaloro F (2010) Characterization of the artisanal fishery and its socio-economic aspects in the central Mediterranean Sea (Aeolian Islands, Italy). Fish Res 102:87-97

Bello G (1991) Role of cephalopods in the diet of the swordfish, Xiphias gladius, from the eastern Mediterranen sea. Bull Mar Sci 49(1-2):312-324

Bello G (1993) Tremoctopus violaceus (Cephalopoda: Tremoctopodidae) in the stomach content of a swordfish from the Adriatic Sea. Boll Malacol 29:45-48

Bello G (1996) Teuthophagous predators as collectors of oceanic cephalopods: the case of the Adriatic Sea. Boll Malacol 32(1-4):71-78

Bello G (1999) Cephalopods in the diet of albacore, Thunnus alalunga, from the Adriatic Sea. J Molluscan Stud 65:233-240

Block BA, Dewar H, Blackwell SB, Williams TD, Prince ED, Farwell CJ, Boustany A, Teo SLH, Seitz A, Walli A, Fudge D (2001) Migratory movements, depth preferences, and thermal biology of Atlantic bluefin tuna. Science 293:1310-1314

Block BA, Teo SLH, Walli A (2005) Electronic tagging and population structure of Atlantic bluefin tuna. Nature 434:1121-1127

Bustamante P, Caurant F, Fowler SW, Miramand P (1998) Cephalopods as a vector for the transfer of cadmium to top marine predators in the north-east Atlantic Ocean. Sci Total Environ 220(1):71-80

Canese S, Garibaldi F, Giusti M, Romeo T, Greco S (2004) First successful attempt of swordfish tagging with popup in the Mediterranean Sea. Biol Mar Medit 11:153

Canese S, Garibaldi F, Orsi Relini L, Greco S (2008) Swordfish tagging with pop-up satellite tags in the Mediterranean Sea. ICCAT Coll Vol Sci Pap 62(4):1052-1057 
Carey FG, Robinson BH (1981) Daily patterns in the activities of swordfish, Xiphias gladius, observed by acoustic telemetry. Fish Bull 79:277-292

Carey FG (1990) Further acoustic telemetry observation of swordfish. In Planning the future of billfishes, research and management in the 90s and beyond. In: Stroud RH (ed) Kailua-Kona, Hawaii: Proceedings of the second international billfish symposium 2 pp 103-122

Castriota L, Finoia MG, Campagnuolo S, Romeo T, Potoschi A, Andaloro F (2008) Diet of Tetrapturus belone (Istiophoridae) in the central Mediterranean Sea. J Mar Biol Assoc UK 88(1):183-187

Cherel Y, Duhamel G, Gasco N (2004) Cephalopod fauna of subantarctic islands: new information from predators. Mar Ecol Prog Ser 266:143-156

Clarke MR (1962a) The identification of cephalopod "beaks" and the relationship between beak size and total body weight. Bull $\mathrm{Br}$ Mus (natural history). Zoology 8:419-480

Clarke MR (1962b) Significance of cephalopod beaks. Nature 193:560-561

Clarke MR (1977) Beaks, nets and numbers. Symp Zool Soc London 38:89-126

Clarke MR (1980) Cephalopoda in the diet of sperm whales of the southern hemisphere and their bearing on sperm whale biology. Discov Rep 37:1-324

Clarke MR (1986) A handbook for the identification of cephalopods beaks. Clarendon Press, Oxford

Clarke MR (1996a) The role of cephalopods in the world's oceans: an introduction. Philos Trans R Soc Lond B 351:979-983

Clarke MR (1996b) The role of cephalopods in the world's oceans: general conclusion and the future. Phil Trans R Soc Lond B 351:1105-1112

Consoli P, Romeo T, Battaglia P, Castriota L, Esposito V, Andaloro F (2008) Feeding habits of the albacore tuna Thunnus alalunga (Perciformes, Scombridae) from central Mediterranean Sea. Mar Biol 155:113-120

Cosgrove R, Arregi I, Arrizabalaga H (2006) Archival tagging of albacore (Thunnus alalunga) in the North Atlantic, a pilot study. ICCAT Coll Vol Sci Pap 59(3):923-927

De Metrio G, Arnold GP, De La Serna GM, Block BA, Megalofonou P, Lutcavage M, Oray I, Deflorio M (2005) Movements of bluefin tuna (Thunnus thynnus L.) tagged in the Mediterranean Sea with pop-up satellite tags. ICCAT Coll Vol Sci Pap 58(4):1337-1340

Di Natale A, Mangano A (2008) CPUE series (1985-2006) by gear type in the Tyrrhenian sea and in the Strait of Sicily. ICCAT Coll Vol Sci Pap 62(4):1128-1141

Di Natale A, Mangano A, Celona A, Valastro M (2005) Size frequency composition of the Mediterranean spearfish (Tetrapturus belone, Rafinesque) catches in the Tyrrhenian Sea and in the Straits of Messina in 2003. ICCAT Coll Vol Sci Pap 58(2):589-595

Giordano D, Busalacchi B, Bottari T, Perdichizzi F, Profeta A, Perdichizzi A, Pirrera L, Modica L, Rinelli P (2010) Population dynamics and distribution of Eledone cirrhosa (Lamarck, 1798) in the Southern Tyrrhenian Sea (Central Mediterranean). Cah Biol Mar 10:213-227

Guerra A (1992) Mollusca-Cephalopoda. In: Ramos MA et al (eds) Fauna iberica, Vol 1. Museo Nacional de Ciencias Naturales, CSIC, Madrid

Guglielmo L, Crescenti N, Costanzo G, Zagami G (1995) Zooplankton and micronekton communities in the Straits of Messina. In: Guglielmo L, Manganaro A, De Domenico (eds) The straits of Messina ecosystem. Messina, pp 247-269

Hyslop EJ (1980) Stomach content analysis: A review of methods and their application. J Fish Biol 17:411-422
Jereb P, Roper CFE (2005) Cephalopods of the world. An annotated and illustrated catalogue of cephalopod species known to date. Volume 1. Chambered nautiluses and sepioids (Nautilidae, Sepiidae, Sepiolidae, Sepiadariidae, Idiosepiidae and Spirulidae). In: FAO Species Catalogue for Fishery Purposes. Rome, FAO 4(1), pp 262

Karakulak FS, Salman A, Oray IK (2009) Diet composition of bluefin tuna (Thunnus thynnus L. 1758) in the eastern Mediterranean sea, Turkey. J Appl Ichthyol 25(6):757-761

Lansdell M, Young J (2007) Pelagic cephalopods from eastern Australia: species composition, horizontal and vertical distribution determined from the diets of pelagic fishes. Rev Fish Biol Fish 17:125-138

Lentini F, Romeo T (2000) Studio sulla pesca nelle Isole Eolie. Biol Mar Medit 7(2):765-769

Lu CC, Ickeringill R (2002) Cephalopod beak identification and biomass estimation techniques: tools for dietary studies of southern Australian finfishes. Mus Vic Sci Rep 6:65

Lutcavage ME, Brill RW, Skomal GB, Chase BC, Goldstein JL, Tutein J (2000) Tracking adult North Atlantic bluefin tuna (Thunnus thynnus) in the northwestern Atlantic using ultrasonic telemetry. Mar Biol 137:347-358

Nakamura I (1985) Billfishes of the world. An annotated and illustrated catalogue of marlins, sailfishes, spearfishes and swordfishes known to date. FAO Fish Synop 125:65

Olson RJ, Watters GM (2003) A model of the pelagic ecosystem in the eastern tropical Pacific Ocean. Bull I-ATCC 22:133-217

Palko BJ, Beardsley GL, Richards WJ (1981) Synopsis of the biology of the swordfish, Xiphias gladius Linnaeus. NOAA Tech Rep NMFS Circ 441:2-15

Pedà C, Malara D, Battaglia P, Perzia P, Andaloro F, Romeo T (2009) I cefalopodi nella dieta di grandi pelagici: identificazione dei becchi e costituzione di un archivio fotografico di riferimento. Biol Mar Medit 16(1):354-355

Peristeraki P, Tserpes G, Lefkaditou E (2005) What cephalopod remains from Xiphias gladius stomachs can imply about predator-prey interactions in the Mediterranean Sea. J Fish Biol 67:549-554

Piatkowski U, Pierce GJ, Morais da Cunha M (2001) Impact of cephalopods in the food chain and their interaction with the environment and fisheries: an overview. Fish Res 52:5-10

Pinkas L, Olipham MS, Iverson ILK (1971) Food habits of albacore, bluefin tuna and bonito in Californian waters. Fish Bull Calif Dept Fish Game 152:1-105

Quetglas A, de Mesa A, Ordines F, Grau A (2010) Life history of the deep-sea cephalopod family Histioteuthidae in the western Mediterranean. Deep-Sea Res I 57:999-1008

Romeo T, Consoli P, Castriota L, Andaloro F (2009) An evaluation of resource portioning between two billfish, Tetrapturus belone and Xiphias gladius, in the central Mediterranean Sea. J Mar Biol Assoc UK 89(4):849-857

Roper CFE, Sweeney MJ, Nauen CE (1984) FAO species catalogue. Vol. 3. Cephalopods of the world. An annotated and illustrated catalogue of species of interest to fisheries. FAO Fish Synop 125(3):277

Salman A (2004) The role of cephalopods in the diet of swordfish (Xiphias gladius Linnaeus, 1758) in the Aegean Sea (Eastern Mediterranean). Bull Mar Sci 74(1):21-29

Salman A, Karakulak FS (2009) Cephalopods in the diet of albacore Thunnus alalunga, from the eastern Mediterranean. J Mar Biol Assoc UK 89(3):635-640

Santos MB, Clarke MR, Pierce GJ (2001) Assessing the importance of cephalopods in the diets of marine mammals and other top predators: problems and solutions. Fish Res 52:121-139 
Sarà G, Sarà R (2007) Feeding habits and trophic levels of bluefin tuna Thunnus thynnus of different size classes in the Mediterranean Sea. J Appl Ichthyol 23:122-127

Sinopoli M, Pipitone C, Campagnuolo S, Campo D, Castriota L, Mostarda E, Andaloro F (2004) Diet of young-of-the-year bluefin tuna, Thunnus thynnus (Linnaeus, 1758), in the southern Tyrrhenian (Mediterranean) Sea. J Appl Ichthyol 20(4):310-313

Takahashi M, Okamura H, Yokawa K, Okazaki M (2003) Swimming behaviour and migration of a swordfish recorded by an archival tag. Mar Freshw Res 54:527-534

Thomas RF (1977) Systematics, distribution, and biology of cephalopods of the genus Tremoctopus (Octopoda: Tremoctopodidae). Bull Mar Sci 27:353-392

Tsuchiya K, Okamata H, Uozumi Y (1998) Cephalopods eaten by pelagic fishes in the tropical east Pacific, with special reference to the feeding habit of pelagic fish. La Mer 36:57-66

Velasco F, Olaso I, Sánchez F (2001) The role of cephalopods as forage for the demersal fish community in the southern Bay of Biscay. Fish Res 52:65-77
Villari A, Ammendolia G (2009) On a beached specimen of Octopoteuthis sicula (Cephalopoda: Octopoteuthidae) in the Strait of Messina. Boll Malacol 45:9-11

Voss GL (1953) A contribution to the life history and biology of the sailfish, Istiophorus americanus Cuv. and Val., in Florida waters. Bull Mar Sci 3:206-240

Wolff GA (1982) A beak key for eight eastern tropical Pacific cephalopod species with relationships between their beak dimensions and size. Fish Bull 80(2):357-370

Wolff GA (1984) Identification and estimation of size from the beaks of 18 species of cephalopods from the Pacific Ocean. NOAA Tech Rep NMFS 17:50

Zumholz K, Piatkowski U (2005) Research cruise data on the biology of the lesser flying squid, Todaropsis eblanae, in the North Sea. Aquat Living Resour 18:373-376 